\title{
Visiones ante el umbral: el discurso iconográfico de la galería porticada de Rebolledo de la Torre
}

\author{
Visions facing the threshold: the iconographic discourse of \\ the Romanesque portico of Rebolledo de la Torre
}

José Arturo SALGADO PANTOJA

Universidad de Castilla-La Mancha

Recibido: 12-IV-2016

Aceptado: 6-VI-2016

Resumen: En este artículo se analiza la galería porticada de Rebolledo de la Torre (Burgos) desde una perspectiva iconográfica. Esta majestuosa obra románica, construida en 1186 por el taller de Juan de Piasca, presenta en sus capiteles y canecillos un mensaje ordenado y comprensible en el que se alude al origen y las consecuencias del pecado, así como a la necesidad de combatirlo con las armas de la fe y la virtud.

Palabras clave: Románico, Pórtico, Escultura, Arquitectura, Iconografía, Simbolismo, Burgos, Juan de Piasca.

ABSTRACT: In this article the portico of Rebolledo de la Torre (Burgos) is analyzed from an iconographic perspective. This majestic Romanesque structure, built in 1186 by Juan de Piasca's workshop, shows in their capitals and corbels an ordered and understandable message referring to the origin and consequences of sin, and the need to fight it with the weapons of faith and virtue.

Keywords: Romanesque, Portico, Sculpture, Architecture, Iconography, Symbolism, Burgos, Juan de Piasca.

Las labores de estudio y catalogación llevadas a cabo en tierras burgalesas desde los inicios del siglo XX han sido fundamentales para el conocimiento y la salvaguarda de buena parte del patrimonio artístico provincial. La primera monografía dedicada de forma exclusiva a ese fin fue el Catálogo Monumental y Artístico de la provincia de Bur- gos de Narciso Sentenach ${ }^{1}$, una formidable compilación de siete volúmenes cuya finalización precisó de hasta tres prórrogas, en gran medida debido a la vasta extensión del

\footnotetext{
${ }^{1}$ N. SENTENACH Y CABAÑAS, Catálogo Monumental y Artístico de la Provincia de Burgos, 7 vols., Biblioteca Tomás Navarro Tomás (CSIC), manuscrito inédito, Madrid, 1921-1924.
} 
territorio a analizar y a la ingente cantidad de núcleos poblados y deshabitados existentes en él. Estos y otros inconvenientes, más que excusables en los inicios de la década de 1920, propiciaron que algunas localidades pasasen desapercibidas: tal fue el caso de Rebolledo de la Torre, cuyo mínimo caserío se asienta en los confines occidentales de la Comarca de Páramos, a escasísima distancia del límite palentino.

Las pesquisas efectuadas por el historiador Luciano Huidobro en el partido judicial de Villadiego, recogidas en el Boletín de la Comisión Provincial de Monumentos Históricos y Artísticos de Burgos de 1923, pusieron de manifiesto la existencia de algunas obras artísticas de gran relevancia en la zona. Una de las que más llamó su atención fue precisamente la iglesia parroquial de la citada población, y muy en especial "el elegante atrio de arcos tapiados, que debían ser descubiertos, para poder admirar sus soberbios capiteles del siglo XII". También se interesó por la existencia de un testimonio epigráfico grabado en un ventanal del mismo, donde alcanzó a leer la fecha de 1186 y los nombres de Domingo y Pelagio $^{2}$.

Esta breve noticia excitó la curiosidad de Leopoldo Torres, que de forma casi inmediata tomó el tren que conectaba Madrid con Santander, deteniendo su viaje en la estación palentina de Alar del Rey. Tras hora y media de marcha, por fin avistó la destacada silueta del torreón medieval inmortalizado en el apellido toponímico de Rebolledo, así como el majestuoso templo dedicado a los Santos Julián y Basilisa. Una vez a los pies de este edificio, focalizó su atención en la galería porticada, hermosa aunque ensombrecida por los desafortunados aditamentos seculares. Las arquerías permanecían cegadas al menos desde 1794, cuando se invirtieron 36 reales en los materiales necesarios para

${ }^{2}$ L. HUIDOBRO SERNA, “Comunicación del Conservador de la Comisión Sr. Huidobro. Investigaciones en los Partidos de Sedano y Villadiego", Boletín de la Comisión Provincial de Monumentos Históricos y Artísticos de Burgos, no 4, 1923, p. 123. "cerrar el pórtico"3, mientras que el espacio interno se encontraba subdividido en dos pisos, mostrando una extraña compartimentación ya descrita en los libros de fábrica del siglo $\mathrm{XIX}^{4}$.

El arquitecto madrileño elogió la finísima labra de los capiteles que exornaban el recinto, pero la imposibilidad de observarlos de forma íntegra le obligó a centrar su estudio de forma exclusiva en la inscripción situada en la cara externa del vano occidental. Tras conseguir una escalera de madera, ascendió por sus peldaños hasta el epígrafe medieval, logrando transcribir una gran parte de su contenido ${ }^{5}$. La lectura completa del mismo y su interpretación definitiva se produjo gracias a la ulterior labor de otros autores, que consiguieron esclarecer el nombre del artífice de la obra: Juan de Piasca ${ }^{6}$ (Fig. 1).

La creciente fascinación por este pórtico románico, único no sólo por su valor artístico, sino ya también por su indudable

\footnotetext{
${ }^{3}$ Archivo Diocesano de Burgos (en adelante ADB), Sección Parroquias, Rebolledo de la Torre, Caja 3ª, Libro de Fábrica II, 1794, fol. 7v.

${ }^{4}$ Ibídem, Libro de Inventarios, 27 de junio de 1824, fol. 6v. y Libro de Fábrica II, legajo suelto, 1874, fol. 37r.

${ }^{5}$ L. TORRES BALBÁS, “Un maestro inédito del siglo XII", Archivo Español de Arte y Arqueología, nº 1, 1925, p. 322.
}

${ }^{6}$ J. GUDIOL I RICART y J. A. GAYA NUÑO, Arquitectura y Escultura Románicas, "Ars Hispaniae: vol. 5", Madrid, 1948, pp. 301 y 303. J. PÉREZ CARMONA, Arquitectura y escultura románicas en la provincia de Burgos, Burgos, 1959, p. 42. J. L. HERNANDO GARRIDO, “Escultores en el Románico del Norte de Castilla: itinerancias y anonimatos. Reflexiones sobre Rebolledo de la Torre (Burgos) y Santa María de Piasca (Cantabria)", en Los protagonistas de la obra románica, Aguilar de Campoo, 2004, p. 167. Alejandro García Morilla, en un estudio reciente, ofrece la siguiente traducción: "Yo, el abad Domingo, poblé este lugar de Vallejo desde sus fundamentos en unión de mi hermano Pelayo el año 1186. † El señalado día 22 de diciembre del año 1186, hizo este pórtico el maestro Juan de Piasca. Cuando fue poblado este solar de Vallejo (era) behetría de Q. Gonzalo Peláez". A. GARCÍA MORILLA, "El conjunto epigráfico de Rebolledo de la Torre. Un ejemplo singular de actividad publicitaria a finales del siglo XII", Medievalismo, $\mathrm{n}^{\mathrm{o}}$ 24, 2014, pp. 118-119. 


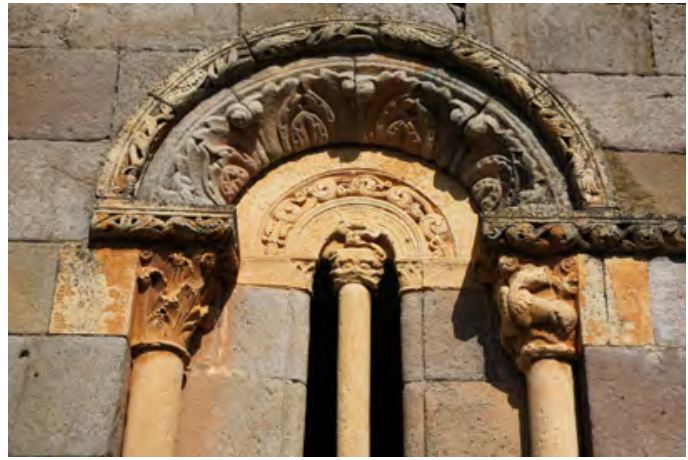

- Fig. 1. Inscripción en el ventanal oeste del pórtico. Rebolledo de la Torre (Burgos). Foto del autor.

cronología y autoría, propició que Irineo Villalobos, párroco local, sugiriese al Arzobispado de Burgos la necesidad de efectuar una intervención encaminada a dignificar su aspecto. La respuesta no se hizo esperar y en 1928 se retiraron todos los añadidos postmedievales, pese a las reticencias de una gran parte de los parroquianos ${ }^{7}$. Las fotografías de la restauración fueron admiradas con entusiasmo por los miembros de la Comisión de Monumentos Históricos y Artísticos de Burgos, que aprobaron en asamblea el pago de una compensación económica de 500 pesetas al cura de la localidad por su "celo y competencia" ${ }^{8}$. Luciano Huidobro, tesorero de la institución y artífice del redescubrimiento, dobló de su propio bolsillo dicha cantidad, contribuyendo de este modo a la instalación de una reja que aún perdura en el acceso del mediodía?.

El valor artístico de los elementos esculpidos, desenmascarados gracias a la limpieza y desescombro de la arquería, supuso un

${ }^{7}$ I. A. VILLALOBOS JIMENO, “Temas de arte burgalés: Atrio románico y fortaleza de Rebolledo de la Torre", Boletín de la Institución Fernán González, no 171, 1968, p. 216.

${ }^{8}$ M. MARTÍNEZ BURGOS, "Historial de la Comisión. Sesión del 11 de Octubre de 1928", Boletín de la Comisión Provincial de Monumentos Históricos y Artísticos de Burgos, nº 25, 1928, p. 380.

${ }^{9}$ ÍDEM, “Historial de la Comisión. Sesión del 20 de Marzo de 1929", Boletín de la Comisión Provincial de Monumentos Históricos y Artísticos de Burgos, n² 27, 1929, p. 445. estímulo fundamental para que el Ministerio de Instrucción Pública y Bellas Artes declarase la iglesia Monumento Histórico Artístico en 1931. Desde entonces, este pórtico burgalés se ha erigido en un destino preferente para los amantes del románico, así como en un foco de inspiración científica para una significativa nómina de investigadores nacionales y foráneos.

La estructura goza en la actualidad de un aspecto renovado y radiante. Se trata de una construcción de planta rectangular, con un ligero acodo al oeste y cubierta con tejado a un agua. Posee unas dimensiones de 17 metros de largo por 4' 5 de ancho, aunque resulta más significativa su altura de 5'75 metros, a todas luces derivada de un recrecimiento del lienzo en época postmedieval para construir el ya referido segundo piso. La galería está adosada al muro meridional del templo, gracias a lo que recibe la generosa luz y la moderada calidez que le brinda el sol en estos rigurosos parajes. Esa iluminación realza la belleza de sus paramentos, obrados con sillares bien canteados de arenisca en los que se observan diversos tonos que abarcan desde el gris basáltico hasta el ocre ferruginoso, dependiendo de la composición específica de cada uno de los bloques.

La arquería se organiza en cuatro tramos bien diferenciados. El tercero de ellos, tomando como referencia el eje oeste-este, forma un breve antecuerpo que aloja la portada de acceso, compuesta por un arco apuntado con arquivoltas que apoyan sobre cuatro capiteles. Los vanos restantes flanquean dicho ingreso en grupos de tres, cuatro y tres huecos de medio punto, todos con chambrana, cimacios y soportes simples o pareados integrados por cestas, fustes y basas. Los tres sectores en los que se ubican quedan individualizados gracias no sólo al retranqueo de sus muros con respecto al del ingreso, sino también por la inclusión de unos elevados fustes dobles que articulan y embellecen los paramentos: existen tres parejas al mediodía y una al oeste, amén del baquetón que anima el vértice suroccidental. Estas columnas rematan en capiteles a 


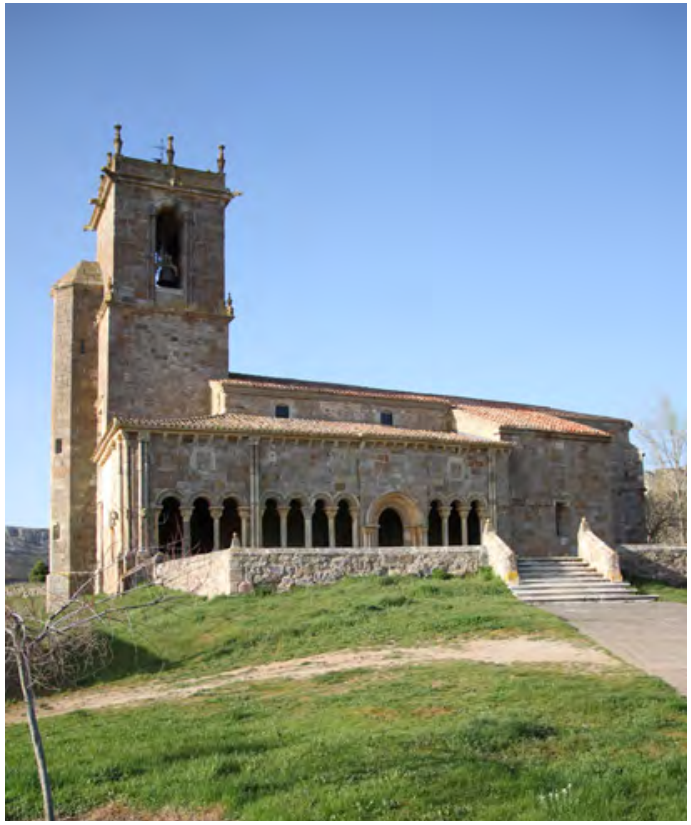

- Fig. 2. Vista exterior del templo parroquial. Rebolledo de la Torre (Burgos). Foto del autor.

la altura de la cornisa, en la que también se despliega un conjunto de treinta y dos canecillos originales, de los cuales sólo cuatro se sitúan a poniente. Este muro lateral contiene además el aludido vano con la inscripción, que resulta ser de medio punto con parteluz y capiteles al exterior, y geminado bajo alfiz al interior (Fig. 2).

\section{EL ORIGEN DEL MAL}

La excesiva rigidez discursiva y la parvedad temática son dos características predominantes en los repertorios visuales de los pórticos románicos castellanos ${ }^{10}$. Frente a esa realidad constatable, destaca una pequeña nómina de casos en los que, como en Rebolledo de la Torre, se expone un conjunto escultórico capaz de transmitir un mensaje ordenado y preciso, a la par que adecuado a los usos y al simbolismo del continente arquitectónico. La "gigantesca psicomaquia" que revela esta obra, empleando una expre-

${ }^{10} \mathrm{~J}$. A. SALGADO PANTOJA, “Imágenes ante portas. Repertorios figurativos en las galerías porticadas castellanas", en La imagen en el edificio románico: espacios y discursos visuales, Aguilar de Campoo, 2015, pp. 92-93. sión de Fernando Cana ${ }^{11}$, se inicia con una majestuosa imagen en relieve de la caída de Adán y Eva. Ese acontecimiento tiene lugar en torno al Árbol de la ciencia, que no sólo actúa como eje central y divisorio de la representación, sino ante todo como un símbolo arquetípico de los principios y consecuencias del Bien y el Mal (Fig. 3).

El árbol enraíza en la enjuta intermedia del vano y cuenta con tres ramas de gran tamaño. La central está coronada con lo que parece ser una paloma alusiva a la presencia divina ${ }^{12}$, mientras que las restantes se desarrollan hacia los laterales. La que ocupa la mitad derecha soporta el peso de la serpiente, que dirige su atención hacia Eva mientras ésta, a modo de remedo, le devuelve la mirada en una deshonesta posición semirreptante. La complicidad visual y somática entre ambas patentiza la debilidad de la mujer ante la tentación, y por ende, su mayor responsabilidad en la caída del linaje humano. Su cuerpo lúbrico y compungido, a medio camino entre la Eva de Saint-Lazare d'Autun y la de la Vera Cruz de Maderuelo, sintetiza a la perfección la actitud de la pecadora y la vergüenza derivada de su condena ${ }^{13}$. Esa concepción bidimensional también se refleja a través de sus manos, pues mientras alarga su diestra para sustraer con osadía el fruto prohibido, exterioriza la pérdida de sus dones preternaturales ocultando su sexo con la hoja de higuera que sostiene en la opuesta.

La perspectiva misógina con la que se aborda el suceso queda enfatizada gracias

\footnotetext{
${ }^{11} \mathrm{~F}$. CANA GARCÍA, Iconografía del románico burgalés, Madrid, 1992, p. 757.

${ }^{12}$ J. M. RODRÍGUEZ MONTAÑÉS, “Rebolledo de la Torre. Iglesia de San Julián y Santa Basilisa", en Enciclopedia del Románico en Castilla y León: Burgos, Aguilar de Campoo, 2009, vol. I, p. 449.

${ }^{13}$ O. K. WERCKMEISTER, "The Lintel Fragment Representing Eve from Saint-Lazare, Autun", Journal of the Warburg and Courtauld Institutes, no 35, 1972, pp. 1-30. A. DE ÁVILA JUÁREZ, “Las pinturas murales de la Vera Cruz de Maderuelo: la misa como recapitulatio", Goya: Revista de arte, no 305, 2005, p. 86. S. SETTIS, La «Tempestad» interpretada, Madrid, 1990, p. 72.
} 


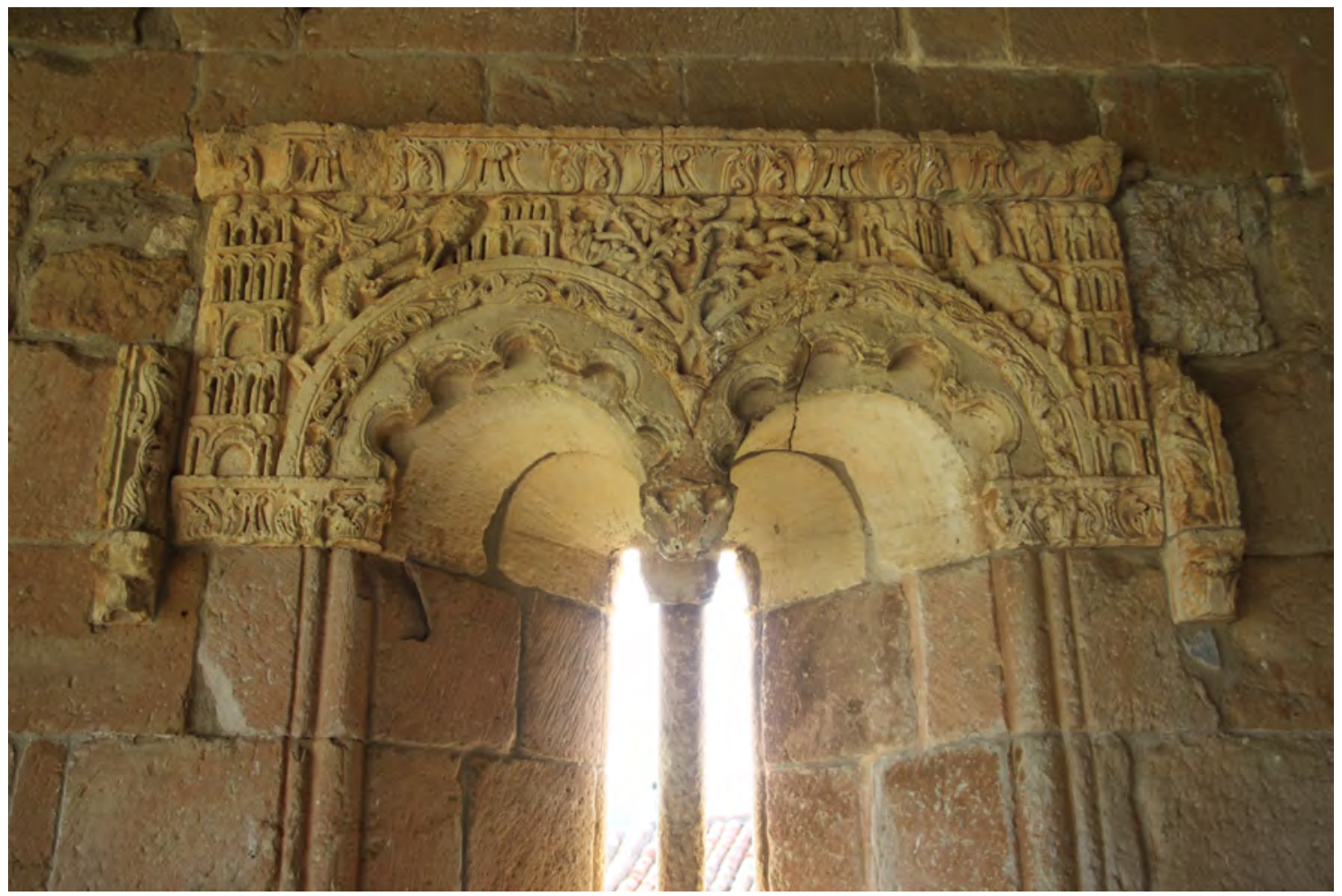

- Fig. 3. El Pecado Original. Rebolledo de la Torre (Burgos). Foto del autor.

a la contraposición gestual que se establece entre Eva y Adán. Mientras que la primera se muestra diligente y despreocupada ante la tentación, su compañero adopta una actitud que contribuye a relativizar su culpa en el pecado original. Él ocupa el espacio triangular de la albanega izquierda, y pese a su anatomía también flexionada y púdica, coloca una de sus manos en el cuello para expresar el atragantamiento que le ha producido su contrición inmediata. Pese a su desesperado intento por no ingerir el fruto que ha tomado por incitación femenina, éste queda atascado en su gaznate, formando un abultamiento a modo de nuez ${ }^{14}$. Esta postura tan teatral resulta desconocida en las representaciones artísticas previas al siglo XII, pero es recurrente durante la Baja Edad Media, lo que ha llevado a sospechar que pueda inspirarse en el lenguaje gestual expresado en los dramas litúrgicos que tenían lugar en

${ }^{14}$ E. FERNÁNDEZ GONZÁLEZ, "Lectura iconográfica del 'Pecado original' a través de la escultura románica de Villaviciosa”, Studium Ovetense, no 6-7, 19781979 , p. 161. las iglesias o ante sus puertas, entre ellos el llamado "Juego de Adán y Eva"15.

La cara externa del ventanal posee decoraciones vegetales que se extienden por la chambrana, la arquivolta, el arco, los cimacios y uno de los capiteles. Las únicas referencias figurativas se concentran en la cesta restante, que contiene dos leones, y en el remate del parteluz, coronado por un monstruoso glouton similar al que se observa en el baquetón del vértice suroeste del pórtico. Hacia el interior, las bellas construcciones torreadas y los carnosos fitomorfos que exornan el alfiz actúan como vagos recuerdos materiales del paraíso terrenal perdido, a la par que como espléndidos reclamos ornamentales que atraen la atención hacia la escena. Ésta se coloca a contraluz, en una privilegiada penumbra desde la que rige el discurso iconográfico de

${ }^{15}$ E. MARTÍNEZ DE LAGOS, “La femme aux serpents. Evolución iconográfica de la representación de la lujuria en el Occidente europeo medieval", Clio $\mathcal{E}$ Crimen, $\mathrm{n}^{\mathrm{o}}$ 7, 2010, p. 145. A. MIGUÉLEZ CAVERO, Gesto y gestualidad en el arte románico de los reinos hispanos: lectura y valoración iconográfica, Madrid, 2010, p. 258. 


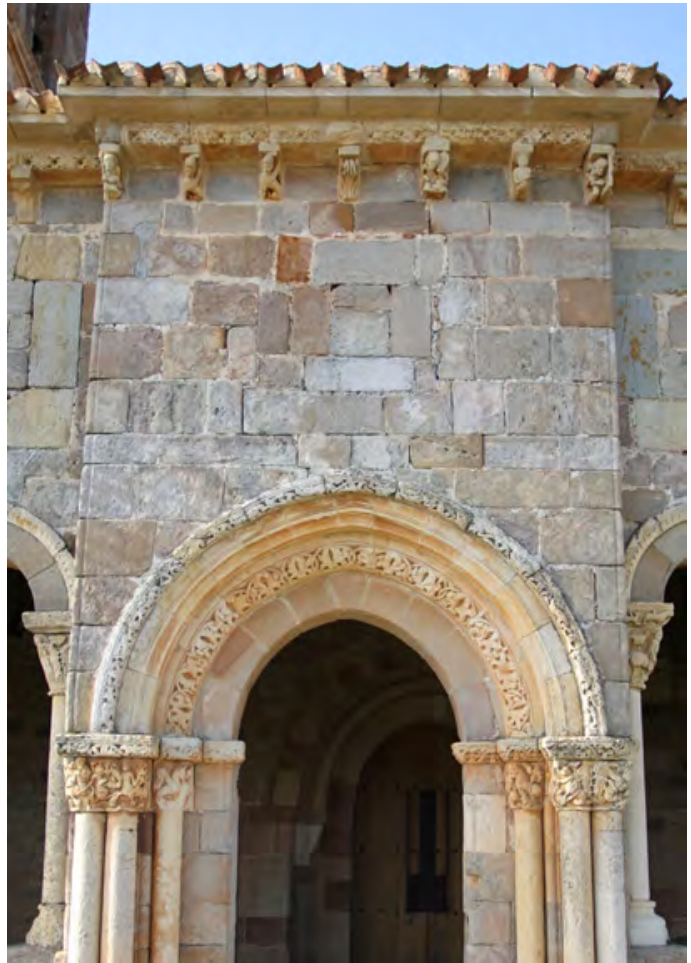

- Fig. 4. Acceso al pórtico. Rebolledo de la Torre (Burgos). Foto del autor.

la estructura, advirtiendo tanto a la feligresía como a los transeúntes que se acogen a ella, catecúmenos y penitentes incluidos ${ }^{16}$, del constante acecho del pecado, traído al mundo por la insubordinación de los protoplastos a las leyes de Dios.

La portada de acceso a la galería se erige en otro dispositivo visual de acusada inten-

\footnotetext{
${ }^{16}$ Esa admonición se amplificaba ante los ojos de los catecúmenos y penitentes, que durante la Edad Media aguardaban fuera de las puertas del templo hasta su definitiva integración en el seno de la comunidad cristiana. C. VOGEL, Le pécheur et la pénitence au Moyen Âge, Paris, 1969, pp. 208-213. I. G. BANGO TORVISO, “La vieja liturgia hispana y la interpretación funcional del templo prerrománico", en ¿Siglos oscuros?: La transición de la Antigüedad al Feudalismo. Actas de la VII Semana de Estudios Medievales, Logroño, 1997, p. 76. A. M. MARTÍNEZ TEJERA, “El «Pórtico románico»: origen y funcionalidad de un espacio arquitectónico intermedio de la edilicia medieval hispana (atrium/porticus/vestibulum)", en Espacios y estructuras singulares del edificio románico, Aguilar de Campoo, 2008, pp. 224-225. M. S. DE SILVA VERSATEGUI, “Espacios para la penitencia pública y sus programas iconográficos en el Románico Hispano", Clio \& Crimen, no 7, 2010, p. 126.
}

ción admonitoria y profiláctica (Fig. 4). Cuatro de los siete canecillos situados en su tejaroz están ocupados por tres músicos tocando diferentes instrumentos y una bailarina que arquea su cuerpo con ímpetu al son de la melodía. La postura acrobática de esta juglaresa y el pergeño demoniaco de su cabello demuestran que no se trata de un espectáculo sacro: muy al contrario, su aspecto exaltado rememora las imágenes románicas de la danza que efectúa Salomé como preludio a la decapitación del Bautista ${ }^{17}$. Las dos arpías que también asisten a esta performance petrificada, una masculina y otra femenina, no dejan lugar a dudas sobre el carácter negativo de la misma ${ }^{18}$. La asociación que se establece entre estas potencias infernales y los citados entretenedores, también presente en la capilla mayor de San Gil de Luna o en la portada de San Martín de Aguilera, explicita aún más la censura moral de la Iglesia hacia esta clase de actuaciones, a menudo celebradas en un ámbito tan digno de respeto como la tierra jurisdiccional del templo ${ }^{19}$.

Los dos capiteles ubicados en los derrames internos de la portada contienen sendas escenas protagonizadas por un dragón y un felino afrontados, y por una pareja de leones que comparten una melenuda testa. Bajo ésta se aprecia una faz zoomorfa vomitando un par de tallos que aprisionan las patas de los cuadrúpedos, cuyos rabos también comienzan a adquirir formas vegetales. El rostro amenazante de estos seres concuerda a la perfección con el mensaje que subyace en las dos cestas extremas. La primera está ocupada por un centauro que tensa su arco para lanzar una flecha a un congénere, que se defiende del ataque con un escudo, mientras que la restante se decora con una pareja de dragones con sus colas entrelazadas y una arpía que dirige su hipnótica mirada hacia

${ }^{17}$ M. E. ARAGONÉS ESTELLA, "Música profana en el arte monumental románico del Camino de Santiago navarro", Príncipe de Viana, nº 199, 1993, p. 249.

18 S. PIETRINI, “Los juglares, cornamusas del diablo: las repercusiones iconográficas de la condena de los entretenedores", Medievalia, nº 15, 2012, p. 298.

${ }^{19}$ J. A. SALGADO PANTOJA, Op. cit., pp. 102-104. 
el umbral de la puerta. La vegetación perturbada que se extiende y retuerce sobre sus cuerpos no es sino un reflejo de la naturaleza irracional y maléfica de las propias presas.

Las bestias y monstruos que se integran en el recuadro inferior de este acceso actúan como aviso dirigido a todos aquellos que se adentran en la antesala del templo; no en vano, las sirenas-ave y los onocentauros, especies semejantes a las que se observan en las referidas cestas externas, son descritas por El Fisiólogo como temibles rivales para la humanidad ${ }^{20}$. Sobre ellos, el semicírculo superior está engalanado con distintos motivos fitomorfos dispuestos con orden y armonía. La puerta reúne aquí todo su simbolismo místico y soteriológico: cualquiera puede cruzarla para acercarse a Cristo, que se autoproclama "la puerta" en el Evangelio de Juan ${ }^{21}$, pero sólo aquellos que se mantienen inmutables en su camino hacia Él, sorteando las tentaciones, pueden franquear el limen hacia la ansiada salvación ${ }^{22}$.

La portada de esta galería porticada plantea otra segunda vía para que el fiel pueda materializar dicho tránsito. Además del acostumbrado paso ritual desde el ámbito profano hacia el Sancta sanctorum, en la correspondiente dirección norte-sur, este ingreso también media en el discurso visual que se despliega en los capiteles de la arquería. Un análisis detenido de los temas presentes en los mismos revela que las referencias a las consecuencias catastróficas del pecado se colocan en los dos sectores de poniente, próximas al ocaso, mientras que los tres arcos situados al este de la puerta proclaman unas esperanzadoras visiones del hombre que combate contra el Mal.

${ }^{20}$ N. GUGLIEMI (ed.), El Fisiólogo: Bestiario medieval, Madrid, 2002, p. 83. J. LECLERQ-MARX, “La sirène et $\mathrm{l}^{\prime}$ (ono)centaure dans le Physiologus grec et latin, et dans quelques Bestiaires. Le texte et l'image", en B. VAN DEN ABEELE (dir.), Bestiaires médiévaux. Nouvelles perspectives sur les manuscrits et les traditions textuelles, Louvain-la-Neuve, 2005, pp. 169-182.

${ }^{21}$ Juan, 10: 7-9.

${ }^{22} \mathrm{~J}$. HANI, El simbolismo del templo cristiano, Barcelona, 2000, p. 76.

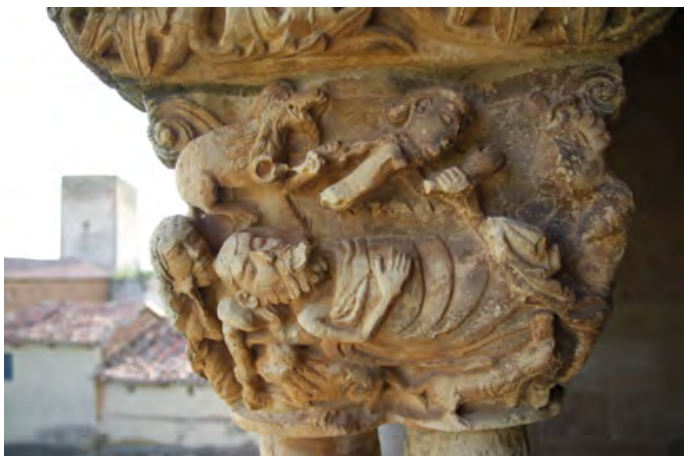

- Fig. 5. La muerte del avaro. Rebolledo de la Torre (Burgos). Foto del autor.

\section{LAS CONSECUENCIAS DEL PECADO}

El tercer capitel del pórtico, si se toma como referencia una distribución oeste-este, ejemplifica una condena al pecado de la avaricia mediante dos escenas que bien podrían inspirarse en la historia del pobre Lázaro y el rico epulón, recogida en el evangelio de Lucas y puesta en boca del propio Jesús. Esta breve parábola relata la inversión de la fortuna de estos dos personajes en el Más Allá con respecto a su situación en la vida terrenal, recurriendo para ello a un topos literario ya empleado en obras como la historia egipcia de Setme y su hijo Si-Osiris o el relato rabínico denominado la Visión del joven estudiante de Ascalón ${ }^{23}$. Lázaro sufre con resignación sus desgracias, pero tras su muerte es acogido en el seno de Abraham; por el contrario, el codicioso recibe la condena eterna tras una vida de suntuosidad desmedida ${ }^{24}$.

El artífice de la pieza centra su atención en la figura del avaro a través de los episodios de su muerte y posterior castigo. La cara oriental muestra el velatorio del difunto, cuyo cuerpo está tendido sobre un jergón junto al que se sitúa su doliente esposa, que apoya una mano en la mejilla exteriorizando un abatimiento físico y moral ${ }^{25}$ (Fig. 5). Esta sen-

\footnotetext{
${ }^{23}$ R. R. CHENOLL ALFARO, “Un capítulo neotestamentario sobre el Más Allá: el rico epulón y el pobre Lázaro", Baetica. Estudios de Arte, Geografía e Historia, no 22, 2000, pp. 319-321.

${ }^{24}$ Lucas, 16: 19-31.

${ }^{25}$ A. MIGUÉLEZ CAVERO, Op. cit., pp. 200-203.
} 
cilla escena terrenal cobra una mayor riqueza expresiva y dramática gracias a la inclusión de otros elementos simbólicos. En primer lugar, dos leones muerden las patas del catre, mientras un tercero amarra con una cadena el cuello del alma del finado, que sale de la boca del cadáver a modo de figurilla humana. Satán, con la ayuda de sus secuaces felinos, tira de ella para arrastrarla consigo al infierno, mientras el aviso de San Pedro parece resonar de fondo: "vuestro adversario el diablo, como león rugiente, anda rondando y busca a quién devorar" 26 .

La ausencia en este caso de las acostumbradas imágenes del banquete o del fallecimiento y ascensión de Lázaro permite conjeturar el probable carácter genérico del avaro que protagoniza la escena ${ }^{27}$. No obstante, un examen detenido de la misma revela varios puntos de conexión con las iconografías más típicas de la citada perícopa evangélica. Uno muy significativo es el pronunciado apéndice que sobresale de la boca del yacente, que a todas luces parece un fragmento del pie del alma que escapa del difunto. Si se acepta esta hipótesis, la fórmula empleada sería idéntica a la que aparece en diferentes versiones de la parábola: en el folio 117v. del Codex Aureus del Escorial ${ }^{28}$, en un capitel absidial de SaintPierre de Vigeois ${ }^{29}$ o en la portada de SaintPierre de Moissac ${ }^{30}$. Otra posibilidad es que el citado elemento sea una exagerada lengua que podría vincularse con la sed espiritual que expresa el condenado a $\mathrm{Abraham}^{31}$, con

${ }^{26}$ I Epístola de San Pedro, 5: 8.

${ }^{27}$ P. RODRÍGUEZ BARRAL, "Reflexiones sobre el castigo de la avaricia y la lujuria a propósito de su representación en la escultura románica catalano-aragonesa", Codex Aquilarensis, no 21, 2005, p. 25.

${ }^{28}$ Codex Aureus Escorialensis. Kommentar in zwei Bänden, Madrid-Münster, 1998, vol. I, pp. 67 y 411-412.

${ }^{29}$ E. PROUST, “Vigeois (Corrèze): un ensemble de chapiteaux historiés en Bas-Limousin", Cahiers de civilisation médiévale, nº 137, 1992, pp. 53-54.

${ }^{30} \mathrm{~F}$. HORVAT y M. PASTOUREAU, Figures romanes, Evreux, 2007, pp. 258-259.

${ }^{31}$ El avaro clama "ten piedad de mí y envía a Lázaro para que, con la punta del dedo mojada en agua,

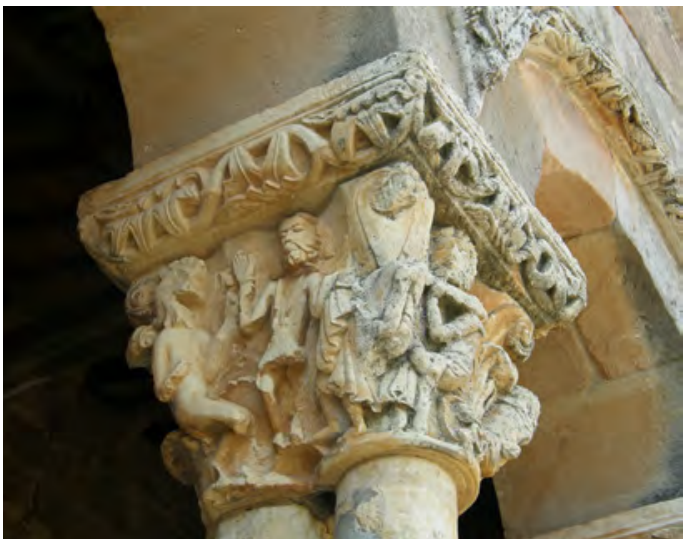

- Fig. 6. El castigo del avaro-guloso. Rebolledo de la Torre (Burgos). Foto del autor.

la glotonería desplegada en sus opulentos festines o incluso con un guiño al ahogamiento que le produce el peso del pecado, tal y como también le ocurre a Judas Iscariote, arquetipo de la codicia ${ }^{32}$.

Los sufrimientos del avaro en el infierno ocupan la cara contraria de la cesta (Fig. 6). El protagonista se encuentra en el centro de la composición, acarreando en su cuello una bolsa henchida de monedas como castigo ejemplar. Sus manos elevadas hacia al cielo indican una solicitud de auxilio divino, un arrepentimiento infructuoso que no impide que un individuo le agarre del cuello, o quizá le despoje de sus vestimentas ${ }^{33}$, deján-

refresque mi lengua, porque estoy atormentado en estas llamas". Lucas, 16: 24.

${ }^{32}$ P. L. HUERTA HUERTA, "Las visiones infernales: pecados, pecadores y tormentos", en Poder y seducción de la imagen románica, Aguilar de Campoo, 2006, pp. 95-96. K. E. WILDGEN. “El capitel del 'Suicidio de Judas' en Autun: un rompecabezas iconográfico", Románico: Revista de arte de amigos del románico, $\mathrm{n}^{\mathrm{o}}$ 4, 2007, p. 31. Cabe indicar que la lengua, y de forma más general la boca, es el foco principal del suplicio que a menudo imponen los demonios a los avaros. Existen numerosos ejemplos de ello en la iconografía románica: J. LECLERQ-MARX, "Le rapport au gain illicite dans la sculpture romane. Entre réalités socio-économiques, contacts de culture et réseaux métaphoriques", Cahiers de civilisation médiévale, no 197,2007 , pp. 58-60.

${ }^{33}$ Existen dos casos parecidos en San Martín de Frómista y San Isidro de Dueñas. M. POZA YAGÜE, "Las portadas de los prioratos cluniacenses de Tierra de Campos en tiempos de Alfonso VI: una iconografía de 
dolo a merced del demonio que lo condujo al averno ${ }^{34}$. Este maligno ser, idéntico al del frente opuesto, combina una cabeza de gallo con cresta de aspecto llameante y un cuerpo humano desnudo y flexionado, de aspecto serpentino. Todas estas características asemejan su figura a la del basilisco, emblema del Mal y la muerte desde la Antigüedad, y símbolo de Satán en el imaginario cristiano.

El afán desordenado por acaparar bienes materiales también es una peligrosa puerta de entrada a otros pecados. La parábola describe al epulón como un hombre vestido de forma suntuosa y que se propina unas espléndidas comilonas diarias, haciendo así una referencia muy explícita a su condición de guloso. Este hecho no pasa desapercibido en la plástica románica, donde a menudo aparece dando buena cuenta de los manjares que se disponen sobre una mesa: así sucede en sendos capiteles de San Martiño de Mondoñedo y Saint-Sernin de Toulouse ${ }^{35}$, en los frescos de Saint-Martin de Nohant-Vic, en un relieve de la seo de Zaragoza o en una metopa de San Martín de Artaiz, donde además está caracterizado como un obeso mofletudo $^{36}$. El capitel de Rebolledo no recoge ese pasaje, pero ofrece en su cara sur una nueva representación del protagonista apo-

corte monástico para una manifestación pública", Anales de Historia del Arte, no 21/2, 2011, pp. 265 y 267.

${ }^{34}$ Un capitel de la portada de Santa Cecilia de Vallespinoso de Aguilar presenta al avaro con la bolsa al cuello, mientras un demonio escamado y con cresta se dispone a aprisionarlo. Otra cesta, situada en el ábside, dispone al pecador entre dos demonios que lo encadenan. J. L. HERNANDO GARRIDO, “La representación del Diablo en la escultura palentina", Codex aquilerensis, no 11,1994 , p. 197.

${ }^{35}$ Concretamente, en un capitel de la Porte des Comtes. M. DURLIAT, La sculpture romane de la route de Saint-Jacques. De Conques à Compostelle, Mont-de-Marsan, 1990, p. 103. D. CAZES y Q. CAZES, Saint-Sernin de Toulouse. De Saturnin au chef d'oeuvre de l'art roman, Graulhet, 2008, p. 112.

${ }^{36}$ M. E. ARAGONÉS ESTELLA, La imagen del mal en el románico navarro, Pamplona, 1996, p. 167. J. MARTÍNEZ DE AGUIRRE, "Artaiz. Iglesia de San Martín”, en Enciclopedia del Románico en Navarra, Aguilar de Campoo, 2008, vol. I, p. 243. yando en su hombro un objeto alargado que sostiene con su mano izquierda. El fuerte desequilibrio hacia atrás que manifiesta su cuerpo demuestra que el elemento que porta no sólo goza de un importante peso material, sino también que ese lastre es parte de la punición que ha de soportar.

La primera opción que se puede barajar al respecto es que se trate de una forzada imagen de perfil de la talega de monedas, cargada a las espaldas del avaro de modo similar a como se expresa en un capitel del crucero de la catedral de Santiago de Compostela. Algunos autores identifican un pez, símbolo recurrente de la lujuria que en Saint-Marcel de Lagraulière ${ }^{37}$, San Martín de Uncastillo y Notre-Dame de Mailhat aparece igualmente asociado al pecado de la avaricia $^{38}$. El gran tamaño del mismo quizá delate el deseo insaciable del glotón, aunque cabe la duda de si un alimento tan moderado y cuaresmal es el más adecuado para expresar una censura al vicio ${ }^{39}$. Desde este punto de vista, resultaría más conveniente un trozo de carne, y muy especialmente porcina, considerada desde la Antigüedad como un manjar distinguido, pero también como una fuente extraordinaria para excitar la tragonería ${ }^{40}$.

\footnotetext{
${ }^{37}$ Los relieves de la portada exhiben la muerte del avaro, su tormento infernal y un personaje que carga a su hombro un pez de enormes dimensiones. Por desgracia, el carácter fragmentario y recolocado de los mismos impide saber cómo se disponían estas imágenes en un origen. C. BOUGOUX, L'imaginerie romane de l'EntreDeux-Mers: l'iconographie raisonnée de tous les édifices romans de l'Entre-deux-Mers, Bordeaux, 2006, pp. 186-187.

${ }^{38}$ El hombre cargado con la bolsa al cuello y la femme aux serpents aparecen representados de forma constante, y a menudo conjunta, en las manifestaciones artísticas del románico. Este hecho revela que ambos pecados, avaricia y lujuria, ocupaban un lugar preeminente en las preocupaciones morales de la Iglesia. P. RODRÍGUEZ BARRAL, Op. cit., p. 9.

${ }^{39}$ J. L. HERNANDO GARRIDO, "La representación...", p. 201. A. GÓMEZ GÓMEZ, El Protagonismo de los otros. La imagen de los marginados en el Arte Románico, Bilbao, 1997, pp. 39-40.

${ }^{40}$ M. W. ADAMSON, Food in Medieval Times, Westport, 2004, p. 83.
} 


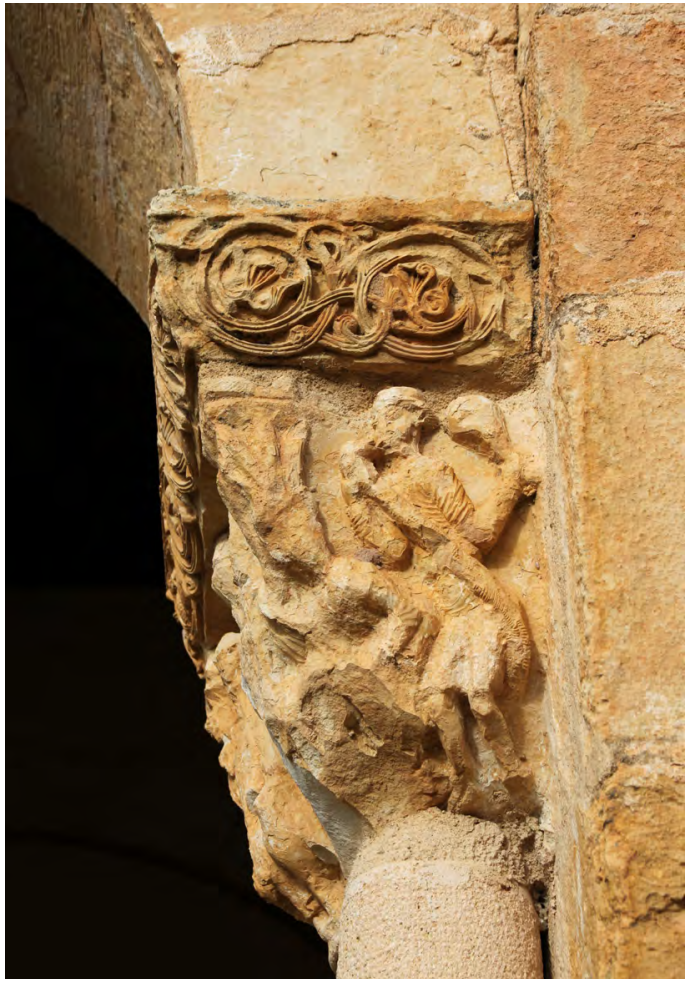

- Fig. 7. El castigo del guloso. Iglesia de San Juan Bautista, Orejana (Segovia). Foto del autor.

Los frescos oscenses de Ordovés y Sieso de Jaca, hoy en el Museo Diocesano de Jaca, contienen sendas alegorías de la gula expresadas a través de un jinete que cabalga sobre un marrano mientras levanta en su mano un jamón ${ }^{41}$. Este iconograma resulta casi desconocido en el románico, aunque se refleja en un capitel del pórtico segoviano de San Juan Bautista de Orejana (Fig. 7). En él comparten espacio varios personajes muy erosionados, entre ellos uno que monta en un cerdo sobre el que también campea un ser de aspecto demoniaco, similar a otro existente en Sieso de Jaca, y un hombre semiflexionado que blande un pernil animal mientras una serpiente le propina un mordisco en la boca, principal instrumento de su pecado ${ }^{42}$. Las evidentes analogías entre esta imagen y la de Rebolle-

${ }^{41}$ M. E. PIEDRAFITA y M. J. COSTA, “La expresión plástica popular de los pecados capitales a ambos lados del Pirineo", Argensola: Revista de Ciencias Sociales del Instituto de Estudios Altoaragoneses, nº 112, 1998-2002, pp. 181 y 183.

${ }^{42}$ J. A. SALGADO PANTOJA, Op. cit., pp. 99-100. do abren, por tanto, una nueva vía de lectura: el avaro-guloso burgalés bien podría estar acarreando una pieza animal como suplicio adecuado a su voracidad incontrolable.

El tema de la muerte-castigo del avaro invita a reflexionar sobre el carácter perecedero de los bienes materiales, mostrando su inutilidad como instrumentos para alcanzar la vida eterna, y de forma paralela exhorta al arrepentimiento, a la conversión y al cumplimiento de la ley de Cristo. Su colocación frente a la puerta principal del templo subraya esa intención moralizante y admonitoria, tal y como sucede en otras muchas representaciones de este pasaje en el universo románico $^{43}$. Un exemplum recogido por Étienne de Bourbon a mediados del siglo XIII resulta muy elocuente al respecto: "Cuando los novios, llenos de alegría, se disponían a entrar en la iglesia, un usurero de piedra, que había sido esculpido en lo alto del atrio y a quien llevaba un diablo al infierno, cayó con su bolsa sobre la cabeza del usurero vivo y así lo mató" ${ }^{44}$. Tampoco es casual que esta invocación al castigo de la avaricia esté instalada en Rebolledo a escasísima distancia de la imagen de la psicostasis, al igual que sucede en Saint-Amant de Saint-Chamant, Nuestra Señora de Baldós, Santa Cecilia de Vallespinoso de Aguilar, San Martín de Sobrepenilla o Saint-Marcel de Lagraulière, donde un San Miguel cargado con la balanza se sitúa a los pies del lecho mortuorio del rico ${ }^{45}$ (Fig. 8).

${ }^{43}$ Entre otras, en las portadas de Saint-Pierre de Moissac, Saint-Sernin de Toulouse, Saint-Lazare d'Autun, Saint Mary de Lincoln y San Vicente de Ávila, o en los claustros de las catedrales de Girona, Tarragona y Tudela y en el de la abadía de Sant Cugat del Vallès. M. E. ARAGONÉS ESTELLA, La imagen..., p. 115. P. RODRÍGUEZ BARRAL, Op. cit., p. 24. P. A. PATTON, Pictorial Narrative in the Romanesque Cloister. Cloister Imaginery \& Religious Life in Medieval Spain, New York, 2008, p. 173.

${ }^{44}$ Cit. J. LE GOFF, La bolsa y la vida. Economía y religión en la Edad Media, Barcelona, 1987, pp. 84-85. J. BERLIOZ, Saintes et damnés. La Bourgogne du Moyen Âge dans les récits d'Étienne de Bourbon, inquisiteur (1190-1261), Dijon, 1989, pp. 7-9.

${ }^{45}$ P. RODRÍGUEZ BARRAL, Op. cit., p. 26. 


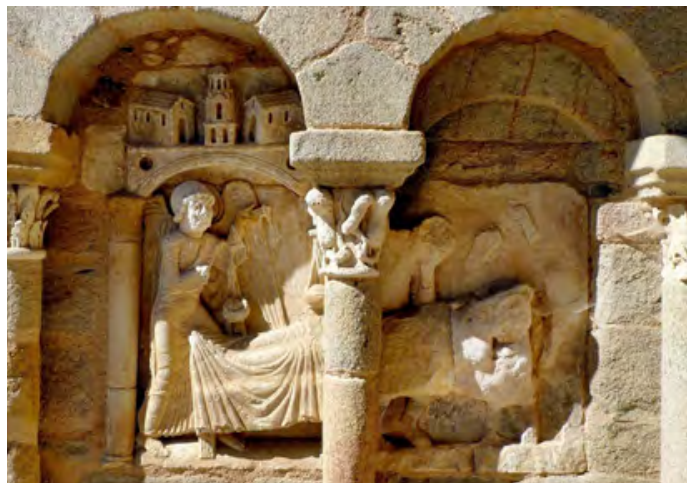

- Fig. 8. El pesaje del alma y la muerte del avaro. Iglesia de Saint-Marcel, Lagraulière (Corrèze, Francia). (C) Martin M. Miles.

\section{EL OCASO DEL ALMA}

El pesaje de las buenas y malas acciones aparece por primera vez en el Egipto faraónico, y todo parece indicar que es en ese mismo contexto geográfico donde se cristianiza varios siglos más tarde. Algunos autores de la Antigüedad como Lactancio, Juan Cristóstomo o San Agustín ya hacen mención al mismo, aunque una de las referencias textuales más explícitas es la que se ofrece en la Vida de Juan el Limosnero, patriarca de Alejandría fallecido en el año 619. Esta narración recoge la historia de Pedro el publicano, un adinerado recaudador de impuestos que durante una grave convalecencia sueña que sus acciones son calibradas mediante una balanza. Los demonios presentes cargan en uno de los platillos todos sus pecados, mientras que los ángeles colocan en el contrario su único gesto de caridad, consistente en la entrega de una pieza de pan a un pobre. Este acto puntual decanta finalmente el juicio hacia la salvación $^{46}$.

La balanza esculpida en el quinto capitel de Rebolledo de la Torre se encuentra flanqueada por San Miguel y el demonio (Fig.

${ }^{46}$ J. BASCHET, “Jugement de l'âme, jugement dernier: contradiction, complémentarité, chevauchement?", Revue Mabillon, no 6/67, 1995, p. 175. P. RODRÍGUEZ BARRAL, "La balanza como instrumento escatológico. El tema del pesaje de las acciones morales en la plástica románica hispánica", Codex aquilarensis, no 24 , 2008, pp. 65-66.

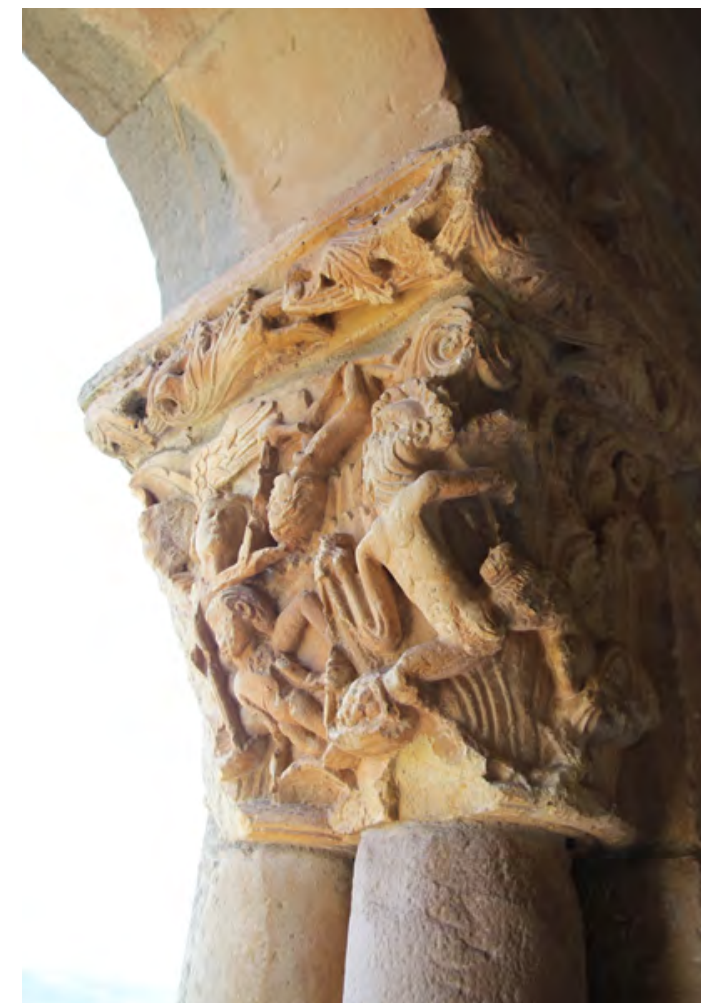

- Fig. 9. El pesaje del alma. Rebolledo de la Torre (Burgos). Foto del autor.

9). El primero perdura muy deteriorado, y aunque se ha perdido casi por completo su cuerpo, aún se aprecian a la perfección sus alas desplegadas. Por su parte, Satán vuelve a ser caracterizado como un ser de sinuosa anatomía antropomorfa, desnudo y con una horrible cabeza rematada por la cresta de gallo. Como suele ser habitual, procura trampear el pesaje ejerciendo fuerza sobre el plato de las acciones reprobables, aunque la gran carga que éste presenta no deja lugar a dudas sobre el resultado del proceso: al contrario de lo que suele ocurrir en la plástica medieval, en este caso particular es negativo.

Esta consideración también se apoya en otras evidencias visuales que ofrece el minucioso artífice de la obra. Junto al arcángel se yergue un misterioso hombre de rostro impávido que aparta de una patada el platillo de las malas acciones, en el que se coloca un individuo que intenta aferrarse sin éxito al extremo contrario. Su figurilla delgada, desnuda y con melena, idéntica a la que expulsa 
el cadáver del avaro por la boca, se repite en la composición dos veces más: la primera se dispone boca abajo sosteniendo la balanza, mientras que la otra es apartada hacia la cara norte por el anticristo, que la mantiene agarrada de la cabellera. Sin duda alguna, se trata de imágenes de una misma alma a través de tres episodios de su juicio: la ponderación, la sentencia y el castigo. Harina de otro costal es el enigmático acompañante de San Miguel, cuya identificación plantea muchas dudas. No obstante, su vehemente repulsa hacia el réprobo incita a pensar en una posible imagen del hombre virtuoso: ¿acaso el mismísimo Lázaro de la parábola, omitido hasta este momento?

El juego dialógico entre este capitel y el del mal rico resulta evidente, e incluso existen indicios suficientes para afirmar que el condenado en la psicostasis es el propio avariento. La elección de este personaje resulta eficaz a la par que económica para un templo parroquial modesto como el de Rebolledo de la Torre, pues a través de un reducido muestrario de relieves protagonizados por un mismo individuo, bien reconocible por los fieles, se logra anatematizar la concupiscencia del ser humano. Cabe señalar que esta invocación a la avaricia como paradigma del pecado no supone un caso aislado en la plástica románica, sino que se inserta dentro de una tendencia común y creciente durante los siglos XI y XII ${ }^{47}$. Dicha evolución temática deriva en gran medida de las renovadas prédicas moralizantes de eclesiásticos como San Ambrosio, Hugo de San Víctor, Gerhoch de Reichersberg o Guido de Anderlecht, muy preocupados por las secuelas del incipiente capitalismo que comienza a desarrollarse en este contexto plenomedieval, entre las que ocupan un lugar destacado la usura, la simonía y la codicia ${ }^{48}$.

${ }^{47}$ J. BASCHET, La sein du père, Paris, 2000, p. 394.

${ }^{48}$ L. K. LITTLE, "Pride goes before Avarice: social change ant the Vices in the Latin Christendom", The American Historical Review, no 76/1, 1971, pp. 20-23. J. HUIZINGA, El Otoño de la Edad Media, Madrid, 1984, pp. $40-41$.
Esa nueva realidad tiene su reflejo en el propio entorno de las iglesias y muy especialmente en sus atrios y pórticos, utilizados con frecuencia desde el Medioevo como ámbitos preferenciales para llevar a cabo diferentes actividades comerciales. $\mathrm{Ni}$ siquiera las severas puniciones establecidas por las autoridades eclesiásticas contra estas costumbres van a conseguir erradicarlas por completo, como demuestran algunas disposiciones sinodales de la Edad Moderna ${ }^{49}$. La imagen tan explícita del trágico destino que aguarda al avariento, por tanto, no sólo debe ser entendida como un recurso visual para exhortar a los parroquianos al ejercicio de la caridad y la mesura, sino como una llamada de atención encaminada a disuadirlos de esas intolerables prácticas que atentan contra el carácter sagrado y respetable de la tierra jurisdiccional del templo.

El capitel que media entre los dos anteriores posee tres hipogrifos dotados de cuerpo de ave, garras delanteras de felino y pezuñas traseras de équido. Esa fisonomía y la amenazante mueca de sus fauces evocan su visión como devoradores de almas, referida por autores medievales como Pierre de Beauvais o en el Bestiario Moralizatto de Gubbio: "por el grifo entiendo al Enemigo, y por el hombre vivo al penitente, que aquél engaña, se come y devora" ${ }^{\prime 50}$. Sin embargo, los protagonistas de esta escena no se encuentran en actitud de ataque ni sometiendo a sus presas, sino consumiendo con placidez los sabrosos frutos, aparentemente uvas, que contienen unos cálices vegetales. La cara interna de la cesta exhibe un pajarillo que se alimenta entre vigorosos tallos, mientras que el cimacio posee una serie de aves de bello plumaje. Todos estos elementos acentúan el carácter ornamental y edénico de la pieza, en la que parece proponerse una elegante fórmula iconográfica para mostrar a las almas santas que participan de las delicias del cie-

${ }^{49} \mathrm{~J}$. A. SALGADO PANTOJA, Pórticos románicos en las tierras de Castilla, Aguilar de Campoo, 2014, p. 275.

${ }^{50}$ Cit. I. MALAXEVERRÍA (ed. y trad.), Bestiario medieval, Madrid, 2008, pp. 138-139 y 141-142. 
lo, convenientemente colocada a espaldas de la psicostasis y frente a la muerte del avaro.

El resto de cestas de las arquerías occidentales, así como los canecillos que adornan la cornisa, presentan una predominancia vegetal, con la inclusión puntual de algún elemento figurativo $^{51}$. En el caso de los primeros, destacan las elegantes hojas rizadas de acanto o helecho entre las que asoman pequeños detalles como una testa humana o un ave que se alimenta de un fruto, amén de los dragones que procesionan en uno de los cimacios. Resulta muy llamativo el ejemplar que corona un espléndido fuste entorchado cuyas acanaladuras se adornan con lises, tetrapétalas y hojas ${ }^{52}$. Su cara oeste exhibe un mascarón felino de cuyas fauces brotan una pareja de tallos perlados que se enredan con otros vástagos que surgen de unos cálices, generando una bella y equilibrada composición. Este mismo tema se repite en uno de los capiteles del alero, aunque en este caso son tres las testas que vomitan los fitomorfos.

\section{LA LUCHA POR LA SALVACIÓN}

La representación figurativa más inmediata y visible desde la puerta del templo ocupa el segundo capitel del sector oriental. La imagen en cuestión se ubica en el extremo noroccidental del mismo y muestra el combate entre un soldado y una sierpe alada (Fig. 10). Él viste cofia y cota de mallas, y porta en sus manos una espada corta y un escudo de gota de agua con el que se defiende de la terrorífica dentellada que le lanza su adversario. Existen dos versiones muy similares de este mismo tema en la ermita de Santa

\footnotetext{
${ }^{51}$ Cabe señalar la calidad escultórica de los elementos vegetales existentes en este pórtico, cuya factura revela unas ciertas conexiones con el arte hispanomusulmán. F. PALOMERO ARAGÓN y M. ILARDIA GÁLLIGO, El arte románico burgalés: un lenguaje plástico medieval actual, León, 1995, p. 84.

${ }^{52}$ Existe un fuste muy parecido en la iglesia cántabra de Santa María de Las Henestrosas de las Quintanillas, que Miguel Ángel García Guinea relacionó con el trabajo de los maestros de Aguilar y San Andrés del Arroyo. M. A. GARCÍA GUINEA, Románico en Cantabria, Santander, 2008, pp. 308-309.
}

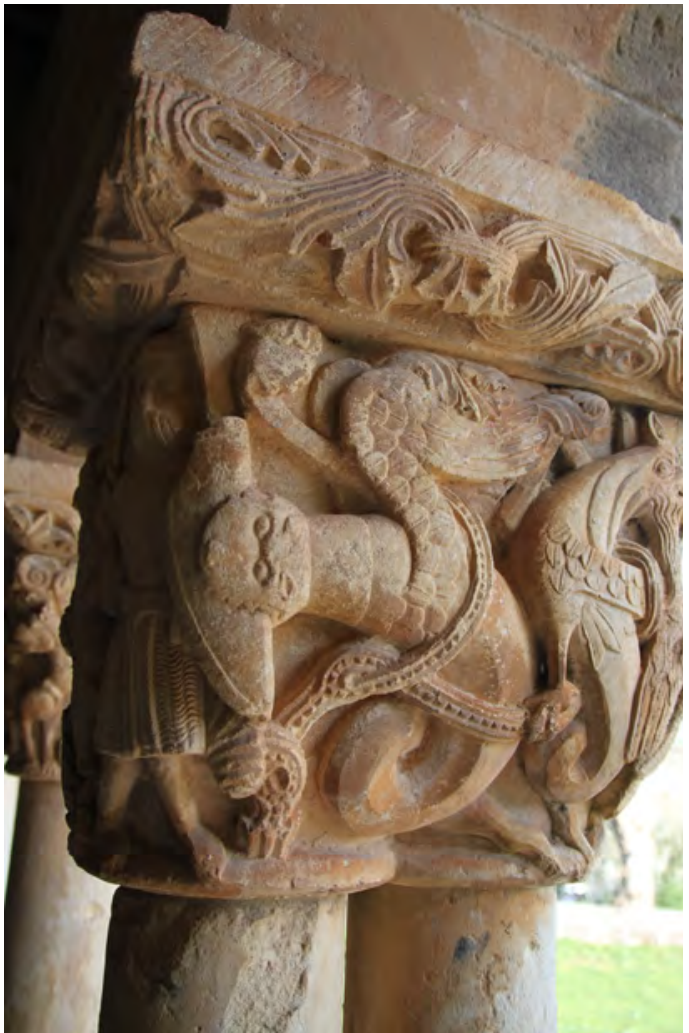

- Fig. 10. El guerrero y la serpiente. Rebolledo de la Torre (Burgos). Foto del autor.

Cecilia de Vallespinoso de Aguilar: una de ellas se sitúa en la portada, mientras que la otra comparte espacio con el pasaje de Sansón desquijarando al león en un capitel del arco triunfal. En ambos casos, el tamaño del reptil es gigantesco, al igual que sucede en la galería burgalesa. José Luis Hernando refiere otros ejemplos cercanos en un capitel de Villavega de Aguilar, en el claustro de Santillana del Mar y en las pilas bautismales de Cantoral de la Peña y Renedo de Valdavia ${ }^{53}$.

El cristiano, firme y blindado, se enfrenta a los envites del pecado, encarnado aquí por el mismo ser contra el que sucumben Adán y Eva en el ventanal de poniente. La tendencia a bestializar el concepto del Mal en la plástica resulta patente a partir de los siglos XI y XII ${ }^{54}$, aunque la elección de la ser-

\footnotetext{
${ }^{53}$ J. L. HERNANDO GARRIDO, “La representación...", p. 194.

${ }^{54} \mathrm{~J}$. A. SALGADO PANTOJA, “Imágenes ante portas...", p. 111.
} 
piente para ese fin es especialmente efectiva. Este ser, vehículo de Satán y germen de la muerte, recibe ya en el inicio de los tiempos una maldición divina que lo condena a reptar y a perecer aplastado por el hombre ${ }^{55}$. Su naturaleza maligna lo erige desde entonces en una de las muestras más temibles de las tentaciones que acechan a la humanidad, causando sin excepción una sensación de temor y rechazo a todos aquellos que la contemplan. La oposición de su figura frente a la del guerrero, por tanto, logra intensificar la declamación apotropaica de esta lucha particular, orientada a abrir las conciencias a la conversión y la reconciliación.

La serpiente del Génesis, traicionera pero aparentemente inofensiva, luce en el mundo terrenal un aspecto aéreo, colosal y terrorífico. El escultor de Rebolledo, a buen seguro alentado por las postulaciones del comitente, despliega además tras ella una selecta comitiva de híbridos destinada a intensificar el estupor de los parroquianos. De ese modo, la superficie de la cesta queda ocupada por las robustas anatomías de dos extraños dragones y cuatro hipogrifos que, al igual que el ofidio, se enredan entre unas bellas cintas perladas. Todos ellos se afrontan formando parejas: los primeros poseen largas chivas, alas, dos poderosas garras delanteras y una gruesa cola de reptil, mientras que los segundos, también barbados y alados, se colocan en posición rampante.

Esta colección de teriomorfos, digna del más creativo bestiario medieval, se acrecienta en el capitel situado inmediatamente hacia levante. Dos arpías masculinas con largas colas serpentinas y cubiertas con un gorro dirigen su hipnótica mirada hacia el interior del pórtico, captando la atención de dos feroces leones. Éstos las flanquean, fijando sus rostros en ellas a la vez que dirigen sus cuartos delanteros en actitud de ataque hacia sendos basiliscos. Se aprecia incluso como uno de ellos clava sus garras en el cuerpo de su contrincante felino, que se

${ }^{55}$ Génesis, 3: 14-15.

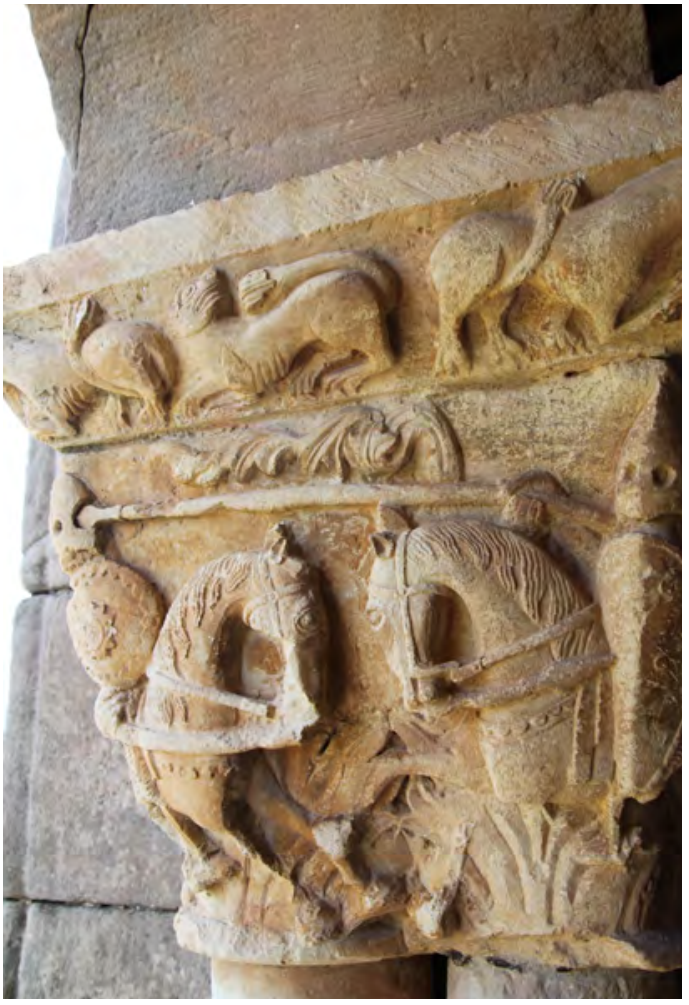

- Fig. 11. Lucha entre caballeros. Rebolledo de la Torre (Burgos). Foto del autor.

revuelve con la clara intención de morderle la cabeza. La figura de un basilisco completa este espectáculo infernal, que frente a las tópicas escenas simétricas y aplantilladas de seres fabulosos existentes en numerosos edificios románicos, aquí tiene la capacidad de producir un brusco impacto psicológico en la audiencia ${ }^{56}$.

La confrontación entre las alegorías del Bien y del Mal concebidas como personajes antagónicos, a la manera prudenciana ${ }^{57}$, se vuelve a vislumbrar en el primero de los cuatro capiteles de este sector oriental, aunque de un modo muy distinto a los anterio-

${ }^{56}$ G. BOTO VARELA, “Representaciones románicas de monstruos y seres imaginarios. Pluralidad de atribuciones funcionales", en El mensaje simbólico del imaginario románico, Aguilar de Campoo, 2007, pp. 90-91.

${ }^{57}$ La célebre Psicomaquia prudenciana gozó de una amplísima difusión durante toda la Alta Edad Media, y su legado conceptual quedó reflejado en numerosas manifestaciones artísticas del románico. A. PRUDENCIO, Obras completas, A. ORTEGA e I. RODRÍGUEZ (eds.), Madrid, 1981, p. 313. 
res. Los rivales son en este caso una pareja de caballeros que se acometen con sus armas, a la usanza de las justas o torneos medievales (Fig. 11). Un examen atento, sin embargo, descubre una serie de detalles que permiten descartar el contenido aparentemente lúdico de la escena. El jinete situado a la izquierda de la composición, pertrechado con rodela, topa su lanza contra el gran escudo oblongo de su adversario, mientras recibe de éste un certero golpe mortal que le atraviesa el yelmo. El caballo del derrotado se detiene en seco, pero el que cabalga el triunfador mantiene su enérgico galope.

Este tema resulta habitual en el románico peninsular, e incluso se repite en otras cinco galerías porticadas: San Esteban de Nieva, San Miguel de Sotosalbos, San Juan de Orejana, Santa María de Tiermes y San Pedro de Caracena ${ }^{58}$. Por regla general, los artífices de estas luchas ecuestres introducen algunos elementos parlantes que permiten contextualizarlas dentro del enfrentamiento bélico en el que se encuentran sumidos los reinos cristianos y al-Andalus. Ese deseo de individualizar a los caballeros es especialmente explícito en Rebolledo de la Torre, donde el musulmán moribundo sobre su montura se afronta al triunfante soldado de Cristo, que con su diestra estocada contribuye a la salvaguarda de un orden social justo, necesario y esencialmente sagrado ${ }^{59}$. El exterminio del infiel y el hereje, elogiado por el mismísimo Bernardo de Claraval, no sólo está justificado, sino que es un deber fundamental para la defensa de Dios y la Iglesia. $\mathrm{Ni}$ siquiera el temor a la muerte debe dete-

\footnotetext{
${ }^{58}$ M. RUIZ MALDONADO, "La lucha ecuestre en el arte románico de Aragón, Castilla, León y Navarra", Cuadernos de Prehistoria y Arqueología, no 3, 1976, pp. 78-79. I. MONTEIRA ARIAS, "La influencia islámica en la escultura románica de Soria", Cuadernos de Arte e Iconografía, $\mathrm{n}^{\mathrm{o}} 27,2005$, pp. 48-51. C. CONSTANTINI, L'iconografia del cavaliere medievale, Todi, 2009, p. 95.

${ }^{59}$ M. LARRAÑAGA ZULUETA, “Representaciones militares en la iconografía románica y legitimación del poder feudal", en E. ILLARREGUI y M. LARRAÑNAGA (coords.), Armamento e iconografía en la Antigüedad y la Alta Edad Media, Segovia, 2008, p. 134.
}

ner al que combate a los enemigos de la fe, pues como recuerda Honoré Bouvet ya en el siglo XIV, los caídos en la guerra santa, libres de pecado mortal, tienen asegurada la salvación $^{60}$.

El pensador medieval Ramón Llull señala el importante valor simbólico que encierran las armas y la indumentaria del caballero cristiano: la lanza ejemplifica la fuerza y la rectitud de la verdad, la loriga es el muro contra los vicios y faltas, la espada es la imagen de la cruz donde Jesús venció a la muerte, y así un largo etcétera ${ }^{61}$. El metal, como no podría ser de otro modo, está reservado a los bellatores, pero los pertrechos morales que subyacen tras él son perfectamente asumibles por los fieles, que deben estar alerta ante las insidias del diablo y bien equipados con lo que San Pablo denomina "la armadura de Dios", compuesta por la "coraza de la justicia", el "escudo de la fe", el "yelmo de la salvación" y la "espada del Espíritu"62.

La pieza que cierra la arquería oriental contiene una bella representación de la victoria de Sansón sobre el león de Timna ${ }^{63}$, vinculada desde la perspectiva formal y decorativa con las existentes en Santa Eufemia de Cozuelos, Santa Cecilia de Vallespinoso de Aguilar o en un capitel del Museo Arqueológico Nacional procedente de Santa María la Real de Aguilar de Campoo ${ }^{64}$ (Fig. 12). Los textos de algunos Padres de la Iglesia ya se ocupan de este pasaje bíblico, sentando las bases para su transformación en un auténtico icono cristológico. Unas centurias más tarde, en los albores del año 1100, la identificación de la lucha entre el héroe del Antiguo Testamento y la bestia como una prefigura de la victoria de Cristo sobre la muerte se encuen-

${ }^{60}$ H. BOUVET, L'Arbre des batailles, Paris, 1883, p. 147.

${ }^{61}$ R. LULIO, Libro del orden de caballería: Príncipes y juglares, J. SUREDA BLANES (trad.), Buenos Aires, 1949, pp. 65-74.

\footnotetext{
${ }^{62}$ Efesios, 6: 10-18.

${ }^{63}$ Jueces, 14: 5-9.

${ }^{64}$ J. M. RODRÍGUEZ MONTAÑÉS, Op. cit., p. 452.
} 


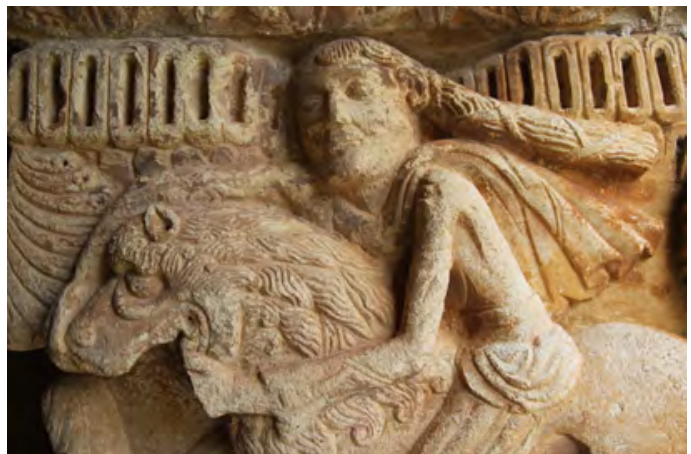

- Fig. 12. Sansón desquijarando al león de Timna. Rebolledo de la Torre (Burgos). Foto del autor.

tra ampliamente difundida en la literatura, y su materialización en el Arte comienza a ser tópica: "VIR GERIT ISTE TUAM, LEO MORTIS, CHRISTE, FIGURA", reza una inscripción que rodea la citada escena en el Ambón de Nicolás de Verdún de la abadía de Klosterneuburg ${ }^{65}$.

Este tema se repite con insistencia en el románico peninsular, y aunque es posible contemplarlo en cualquier ubicación dentro de la topografía templaria, sus resonancias psicomáquicas y escatológicas le proporcionan un lugar destacado en los arcos triunfales y en los accesos de las iglesias. También encuentra un buen acomodo en las galerías porticadas, ya sea en las cornisas como en Nuestra Señora de la Asunción de Duratón, Santa Cristina de Barca o San Ginés de Rejas de San Esteban, o bien formando parte de un capitel como sucede en San Miguel de Sotosalbos y Nuestra Señora de la Asunción de Omeñaca. Estos dos últimos casos muestran una notable coincidencia, pues integran la hazaña del israelita junto a sendas confrontaciones entre dos parejas de caballeros y un guerrero medieval y un león respectivamente, produciéndose así un espléndido maridaje simbólico ${ }^{66}$.

El Sansón de Rebolledo forma una diagonal perfecta con la cesta colocada en el extremo occidental de la cornisa, en la que

${ }^{65}$ ÍDEM, “Prefiguras cristológicas en el arte románico", en El mensaje simbólico..., p. 63.

${ }^{66} \mathrm{~J}$. A. SALGADO PANTOJA, "Imágenes ante portas...", pp. 112-113. se despliega una sintética versión del Sacrificio de Isaac, considerado por los exégetas bíblicos como un anuncio de la Pasión y la Resurrección de Cristo. El vigoroso protagonista de la lucha cuenta con una larga melena trenzada, símbolo de su fuerza, y monta a horcajadas sobre el felino mientras introduce sus manos en las enormes fauces de la bestia. Esta premonición crística se coloca bajo una serie de arquillos y entre dos palmetas angulares, y queda flanqueada por un hombre que amarra con sus manos la cola del león ${ }^{67}$ y un monstruo alado que vomita tallos.

Esta victoria sobre el Mal amplifica el mensaje expresado en los tres capiteles anteriores y refrenda el discurso amonestante y salvífico contenido en el conjunto de la galería porticada. Cristo, a través de la célebre imagen de Sansón, se erige en el modelo a seguir, en la inspiración que ha de guiar a todo fiel en su lucha contra las potencias que encarnan el pecado o contra todos aquellos que pretenden quebrantar la fe cristiana. Gracias a ese valor simbólico, el iconograma consigue un notable éxito en todo el universo románico, e incluso logra un sonoro eco en la literatura medieval.

El célebre Poema de Fernán González, fechado en el siglo XIII, recoge una referencia al citado episodio veterosetamentario en unos términos muy parecidos, estableciendo un símil entre el mismo y entre las luchas de Reconquista contra el caudillo Almanzor: "Entre 1(a) otra terçera de partes de aquilón; / vençremos, non lo dubdes, a este bravo león, / farás tú, si esto fazes, a guisa de Sansón / quando con las sus manos lidió con el bestión" ${ }^{\prime \prime 8}$.

\footnotetext{
${ }^{67}$ Como ya indicó Miguel Ángel García Guinea, este peculiar motivo se repite en la pila bautismal de Osorno, el citado capitel procedente de Santa María la Real, y en otros como los de Moarves de Ojeda, Santa Eufemia de Cozuelos, Dehesa de Romanos o Prádanos de Ojeda. M. A. GARCÍA GUINEA, El Arte Románico en Palencia, Palencia, 1997, p. 60.

${ }^{68}$ F. GONZÁLEZ e H. D. GARCÍA, Poema, vers. 416a-416d, J. HERNANDO PÉREZ (ed.), Salamanca, 2001, p. 282
} 